\title{
Research on the Customer Reputation Evaluation of Large Comprehensive Supermarkets: Data from China
}

\author{
Lingli $\mathrm{LI}^{1, \mathrm{a}}$, Dongdong $\mathrm{CHEN}^{2, \mathrm{~b}^{*}}$ \\ ${ }^{1,2}$ College of Management, Sichuan Agricultural University, Chengdu, Sichuan, China \\ a623872174@qq.com, b10200203@qq.com
}

Keywords: Comprehensive supermarket, Corporate reputation, Customer satisfaction.

\begin{abstract}
Good reputation can create significant social and economic value for the enterprise. Based on the customer perspective, this paper constructed the customer reputation evaluation scale of large-scale comprehensive supermarkets from six dimensions, such as customer orientation, good enterprise, strength and responsibility, etc., and conducted a survey on six large-scale supermarkets in Chengdu, China. The study found that four factors, such as enterprise strength, product quality and development prospect, roughly determine the reputation level of customers in supermarkets, and Chinese customers generally prefer "affordable" comprehensive supermarkets.
\end{abstract}

\section{Introduction}

After entering the Chinese market in the 1990s, the large-scale comprehensive supermarket has been favored by consumers with its excellent and comfortable shopping environment, abundant commodity supply and one-stop shopping experience. As an important part of the retail industry, integrated supermarket occupies an important position in the life of Chinese residents and national economy. The increasingly fierce competition in the retail market has also prompted scholars to pay more and more attention to the comparative competitive advantage of Chinese and foreign large supermarkets [1]. Under the background of the media era, consumers not only rely on traditional parameters such as product price, function and quality to select before making purchases, but also the corporate reputation of selling the product gradually influences consumers' purchasing behavior [2]. Good corporate reputation can reduce consumers' perceived risk, improve consumers' trust, purchase intention and customer satisfaction, which is conducive to the sustainable development of enterprises and the acquisition of competitive advantages [3]. As the terminal of physical sales, comprehensive supermarkets clarify their reputation evaluation in the minds of consumers and conduct targeted management and maintenance, which will help alleviate the huge impact brought by the development of e-commerce industry.

\section{Review}

Corporate reputation, a stakeholder's assessment of a company's past behavior and future prospects, is a key attraction compared to other competitors[4]. As the important intangible asset and strategic resource of the enterprise, different disciplines and theoretical perspectives are different from the connotation of the enterprise's reputation, but they emphasize its importance. Fombrun and Riel summarized various viewpoints and found that enterprise reputation is the effect of enterprise trademark in the market, is a guarantee to maintain and promote the principle of agency, is a good reputation in the accounting field, is the expression of enterprise identity in organizational theory, is a kind of potential market entry barrier in the management field [5]. In enterprise operation, good reputation plays an important role in resource acquisition [6], innovation ability and performance improvement [7], maintenance of market order [8], and word-of-mouth communication of consumers [9]. Customers are the source of profits for enterprises. Most Chinese enterprises are at the stage of reputation formation, and corporate reputation is mainly reflected by customers' perception, which should be paid more attention to [3]. Scholar Wartick also indicates that enterprise reputation is most effective in focusing on direct customers, because customers are the most influential group [10]. As the largest stakeholder of the enterprise, how to evaluate the 
corporate reputation is of vital importance, especially for the supermarket enterprises that directly face the final consumers.

Corporate reputation is closely related to customer satisfaction, customer trust and customer loyalty, and this correlation is positive[10].The reputation of the supermarket's corporate reputation is affecting customer loyalty by the two aspects of charisma and competitiveness [11]. The previous performance of the enterprise affects customer satisfaction and customer loyalty through its influence on corporate reputation [12]. Corporate reputation positively affects customer trust, which has a partial intermediary effect between customer satisfaction, corporate reputation and customer purchase intention [13]. In the study of corporate reputation from the perspective of customers, it is essential for study customer satisfaction, customer trust and customer loyalty.

\section{Research design}

\subsection{Questionnaire}

This paper measures the corporate characteristics of comprehensive supermarkets from the aspects of good enterprise and social responsibility, and measures the reputation of customers in supermarkets from the aspects of customer satisfaction and customer trust. Corporate reputation refers to the five-dimensional scale of Walsh and Beatty [14] and the seven-factor scale of Miao Rong [15]. The scale of ACSI model [16] and Aydin [17] is used for reference to design the evaluation indexes of customer satisfaction, customer trust and customer loyalty. Finally, the customer reputation evaluation index system involving six primary indexes and total of 25 projects was formed, and using likert five-point scale from completely don't agree to fully depict consumer attitudes.

\begin{tabular}{|c|c|c|c|}
\hline $\begin{array}{r}1^{\text {st }} \text { - grade } \\
\text { indexes }\end{array}$ & $2^{\text {nd }}$-grade indexes & $\begin{array}{r}1^{\text {st }} \text {-grade } \\
\text { indexes }\end{array}$ & $2^{\text {nd }}$-grade indexes. \\
\hline $\begin{array}{l}\text { Customer } \\
\text { oriented }\end{array}$ & $\begin{array}{c}\text { Equal treatment of customers (X1) } \\
\text { Focus on buying demand (X2) } \\
\text { Be polite to customers (X3) } \\
\text { Value customer equity (X4) }\end{array}$ & $\begin{array}{l}\text { Customer } \\
\text { satisfaction }\end{array}$ & $\begin{array}{l}\text { Service satisfaction (X16) } \\
\text { Problem solving (X17) } \\
\text { Meet demand (X18) }\end{array}$ \\
\hline $\begin{array}{c}\text { Good } \\
\text { enterprise }\end{array}$ & $\begin{array}{c}\text { Worthwhile work (X5) } \\
\text { Excellent staff (X6) } \\
\text { Generous treatment of employees (X7) } \\
\text { Excellent management ability (X8) } \\
\text { Development potential (X9) } \\
\text { Business vision (X10) }\end{array}$ & Customer trust & $\begin{array}{l}\text { Trusted products and services } \\
\text { (X19) } \\
\text { Integrity management (X20) } \\
\text { Trust marketing products (X21) } \\
\text { Moderate pricing (X22) }\end{array}$ \\
\hline $\begin{array}{l}\text { Strength and } \\
\text { responsibility }\end{array}$ & $\begin{array}{c}\text { Social responsibility awareness (X11) } \\
\text { High quality products (X12) } \\
\text { Strong strength (X13) } \\
\text { Environmental awareness (X14) } \\
\text { Supporting public welfare (X15) }\end{array}$ & Customer loyalty & $\begin{array}{l}\text { Customer stickiness (X23) } \\
\text { Shopping optimization (X24) } \\
\text { Recommended purchase (X25) }\end{array}$ \\
\hline
\end{tabular}

\subsection{Data Collection}

Data were collected through questionnaires, field visits and in-depth interviews. A total of 22 stores were visited in 6 well-known large comprehensive supermarkets in Chengdu region, and 411 questionnaires were distributed and collected, among which 390 were effective and $94.9 \%$ were effective. 
Table 2. Sample demographic characteristics

\begin{tabular}{cccccc}
\hline Characteristics & Classification & Percent & Characteristics & Classification & Percent \\
\hline \multirow{2}{*}{ Gender } & Male & 43 & & $<20000$ & 36 \\
& Female & 57 & Annual & $20000-50000$ & 27 \\
& $20-29$ & 56 & income & $100000-150000$ & 8 \\
Age & $30-39$ & 22 & $($ RMB $)$ & $150000-200000$ & 2 \\
& $40-49$ & 8 & & $>200000$ & 3 \\
& $50-59$ & 6 & & Administration & 3 \\
& Primary schools and below & 5 & & Public Institutions & 16 \\
& Junior high school & 11 & & Enterprise & 22 \\
Education & High school & 22 & Occupation & Merchant & 5 \\
level & Technical school & 18 & & Freelancer & 14 \\
& Bachelor & 40 & & Student & 10 \\
& Graduate and above & 4 & Peasant & 1 \\
\hline
\end{tabular}

\section{Empirical}

\subsection{Statistical test and factor extraction}

Statistical test mainly includes reliability and validity test. Validity analysis is mainly divided into accuracy validity, content validity and architecture validity, in which architecture validity is used to measure the degree to which the tool can measure the theoretical concept. Reliability level reliability, used to detect the reliability degree of data and conclusion, and to explain from the side whether the scale can be stable and reliable to what needs to be measured. The paper adopted the KMO-Bartlett sphericity test and Cronbach's SQ coefficient to test the reliability and validity of the measurement scale and the questionnaire data. The KMO value was tested to be 0.895 , with a small probability of significance $(\mathrm{P}<0.001$ ), and the Cronbach's SQ coefficient was 0.869 . The results of the questionnaire and data were good and could be further analyzed.

Factor analysis is mainly characterized by exploring potential factors that are not easy or unobservable. It is a powerful technical means for data compression and improvement of data quality, which can transform the original variables with mutual dependence and mutual influence into a few comprehensive factors that are almost independent[18]. As the subjective feeling of consumers, reputation is not easy to be observed, which is suitable to be described and refined by factor analysis.

In this paper, SPSS18.0 was used for factor extraction by principal component analysis. After removing 5 variables with less than $50 \%$ of the common factor variance, 7 common factors with feature root greater than 1 were finally obtained, with a cumulative contribution rate of $63.05 \%$ and good effect of factor extraction. According to the factor loading matrix and the original variables, the seven common factors were respectively named strength credibility factor, development factor, customer perception factor, customer loyalty factor, social responsibility factor, trust promotion factor and customer stickiness factor. Seven common factors reflect the reputation of the supermarket from different aspects. Seven common factors reflect the reputation of supermarkets in different aspects. It is hard to make a comprehensive evaluation by using a common factor alone. Therefore, it is necessary to calculate the comprehensive score of the supermarket according to the variance contribution rate corresponding to each common factor. The contribution rate of variance of 7 common factors was 22.08\%, 16.79\%, 15.40\%, $14.85 \%, 12.47 \%, 9.35 \%$ and $9.06 \%$, respectively. The scores and ranking are shown in Table 3. 
Table 3. Scores and rankings

\begin{tabular}{cccccccccc}
\hline Supermarket & FAC1 & FAC2 & FAC3 & FAC4 & FAC5 & FAC6 & FAC7 & Score & Ranking \\
\hline Yonghui & -0.1547 & 0.4525 & -0.1491 & 0.2144 & -0.0367 & -0.1531 & 0.5484 & 0.0815 & 1 \\
\hline Carrefour & 0.0246 & -0.0929 & 0.0225 & 0.3179 & 0.1366 & -0.0637 & 0.0381 & 0.0550 & 2 \\
\hline Ito Yokado & 0.0415 & 0.0140 & 0.2532 & -0.1308 & -0.3049 & 0.2787 & -0.2199 & -0.0008 & 3 \\
\hline Wal-Mart & -0.1594 & -0.2223 & 0.0670 & 0.1934 & 0.1753 & -0.1788 & 0.1002 & -0.0193 & 4 \\
\hline Auchan & 0.1758 & 0.1570 & -0.1240 & -0.2868 & -0.0044 & -0.0798 & -0.1694 & -0.0199 & 5 \\
\hline Ren Renle & -0.0846 & -0.3495 & -0.3757 & -0.3074 & 0.2014 & 0.1884 & 0.0115 & -0.1371 & 6 \\
\hline
\end{tabular}

\subsection{Common factors}

In the 7 common factors, the factor of strength and honesty (Fac1), accounting for 22.08\%, affected the reputation of the supermarket from the aspects of strength and product quality. The weights of three common factors of development (Fac2), customer perception (Fac3) and customer loyalty (Fac4) are all around 15\%. The development prospect, service attitude and whether customers will recommend purchases are important factors influencing customers' trust in the reputation of the supermarket. The cumulative contribution rate of the four common factors of strength integrity, development, customer trust and customer loyalty is $69.12 \%$, which roughly determines the overall customer reputation evaluation level of the supermarket. The weight of social responsibility factor (Fac5) is relatively small, accounting for $12.47 \%$. To some extent, whether the supermarket has environmental awareness and whether it supports public welfare undertakings affects customers' favorable impression of the supermarket.

The variable X21 and the variable X23 are separately extracted as trust promotion factor (Fac6) and customer stickiness factor (Fac7). Whether customers in shopping believe that the products promoted by employees and whether they choose to buy the same products in a more expensive supermarket is directly related to the general impression of the supermarket. Different age groups have different attitudes towards the products promoted by employees. There is a difference of 0.1 level of trust in the products promoted by employees between young people under the age of 40 and middle-aged people over the age of 40 . The middle-aged and the elderly are more likely to trust the goods marketed by staff. When the price of the same product was lower in other supermarkets, $65.64 \%$ of customers would turn to other supermarkets for purchase, and the customers tended to choose supermarkets with lower price overall, and the pursuit of low price was more obvious among middle-aged and elderly customers (Mean 2.09). Factors of trust promotion (Fac6) and customer stickiness (Fac7) are separately extracted in line with the nature of supermarket enterprises and the status quo of Chinese consumers. A large amount of Chinese consumers, especially young people, are reluctant to believe sales practices that are directly tied to salesmen's salaries in most cases, regardless of whether the goods are really cheap and fine.

Table 4. Age and supermarket selection

\begin{tabular}{|c|c|c|c|c|}
\hline Variable & Total sample mean & Age & $\begin{array}{c}\text { Subsample } \\
\text { mean }\end{array}$ & T statistic \\
\hline \multirow{2}{*}{ Fac6（X21） } & \multirow{2}{*}{3.03} & $<40$ & 2.98 & \multirow{2}{*}{$1.89 *$} \\
\hline & & $\geq 40$ & 3.21 & \\
\hline \multirow{2}{*}{ Fac7（X23） } & \multirow{2}{*}{2.19} & $<40$ & 2.24 & \multirow{2}{*}{-1.26} \\
\hline & & $\geq 40$ & 2.09 & \\
\hline
\end{tabular}

*. Correlation is significant at the 0.1 level (2-tailed)

Survey also found that Customers have a weak perception in terms of whether the supermarket pays attention to the purchase demand (X2), whether they pay attention to their rights and interests (X4), whether they are satisfied with the service (X16), as well as the evaluation of supermarket employees (X6) and the treatment of employees (X7), most respondents gave vague answers such as "no feeling" and "not clear". Customers' weak perception of employees' ability and treatment may be attributed to the fact that most of the employees in customer contact are salesmen who have little knowledge of the overall ability and treatment of employees in supermarkets. However, it needs to be further studied whether the Weak awareness of customers' feeling towards the 
indicators such as whether the supermarket attaches importance to rights and interests and whether they are satisfied with the service is caused by the low orientation of enterprise customer.

\subsection{Supermarkets}

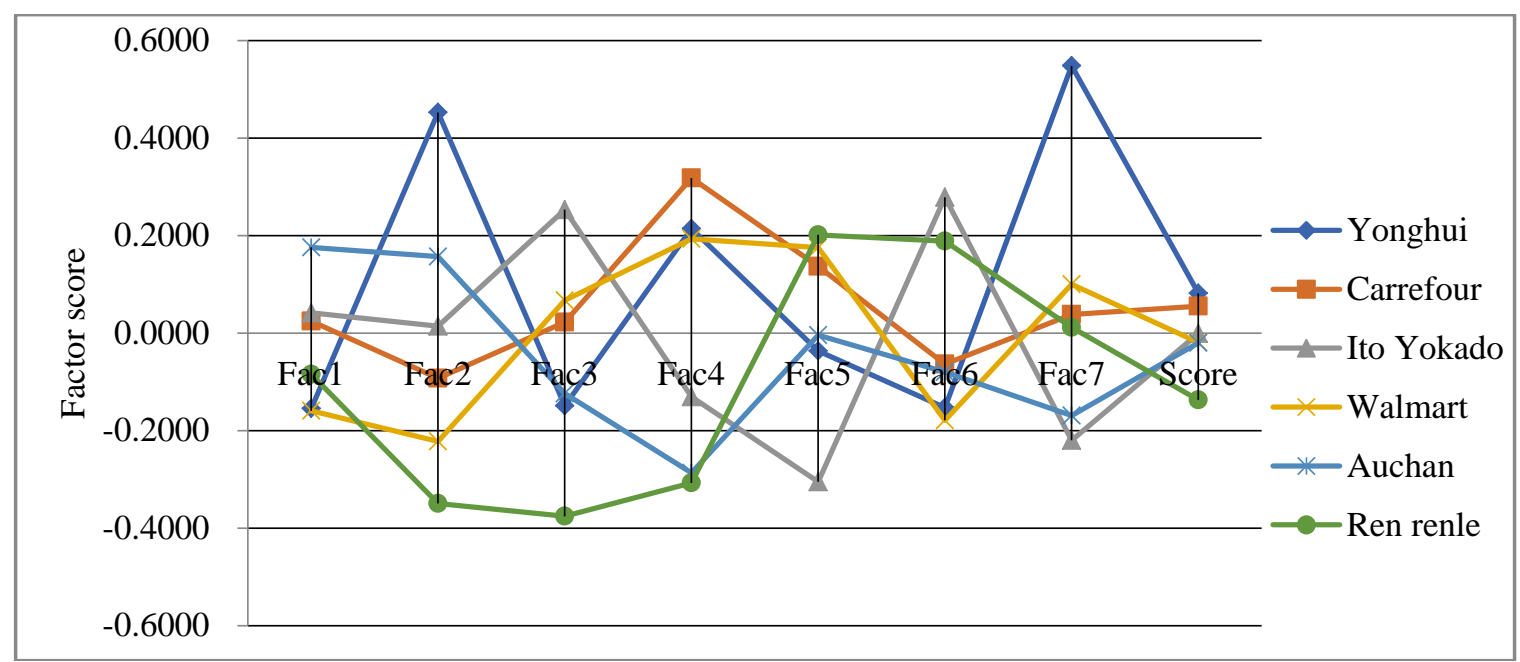

Fig. 1. The factor score line chart

The six supermarkets showed great differences in the factors of development (Fac2) and customer loyalty (Fac7), followed by customer perception (Fac3), customer loyalty (Fac4) and social responsibility (Fac5). According to the overall score, the six supermarkets can be roughly divided into the reputation good group represented by Yonghui and the reputation general group represented by Ren Renle.

Yonghui ranked first in the overall score, performing well in development (Fac2), customer loyalty (Fac4) and customer loyalty (Fac7). Yonghui, as the representative of China's local comprehensive supermarket, is a model of China's "Changing Country-market into Supermarket"(CCIS), a national circulation and agricultural industrialization leading enterprise. It was listed in 2010 and has a strong strength and development potential in the mind of customers. However, it does not have a high evaluation on such indicators as courtesy hospitality and answering customers' questions. In second place, carrefour balanced its growth on various indicators, except that its growth potential (Fac2) and trust promotion (Fac6) were below average. Carrefour is the pioneer of hypermarkets and the second largest international retail chain group in the world. It has been very popular since it entered the Chinese mainland in 1995. However, the lack of supply chain and the excessive power of stores have affected consumers' judgment of its development potential to some extent. ITO, Walmart and Auchan, the third, fourth and fifth largest companies in Japan, the United States and France, are all overseas. Three foreign supermarkets are advanced in management, rich in funds and overseas goods, which are slightly higher than the average level in Fac1 customer trust, and the average performance in Fac4 and Fac5. Compared with domestic supermarkets in China, foreign supermarkets have a short time to enter the Chinese market, with fewer stores, higher prices, limited radiation areas and population, relatively low reputation intensity in the hearts of customers, and relatively few loyal customers. At the bottom of Ren Renle 's ranking, social responsibility (Fac5), trust promotion (Fac6) are higher than the average level, and there is a clear gap between Ren Renle and other supermarkets in terms of development (Fac2), customer perception (Fac3) and customer loyalty (Fac4). Ren renle was founded in Shenzhen, China, one of the top 100 chain companies in China and one of the top private enterprises in China. However, since its listing in 2010, Ren Renle has suffered heavy losses. Customers are worried about its development prospect and the overall reputation level is low. According to the survey, while winning the popularity of middle-aged and elderly consumers with low prices, Ren Renle has lost many young customers due to the poor attitude of employees and poor environment of stores. 


\section{Conclusion, limitations and further research}

\subsection{Conclusion}

The main conclusions of this paper are as follows: 1 . Customers' perception of the reputation of the comprehensive supermarket mainly comes from the strength, product quality, development potential and shopping experience of the supermarket enterprise. 2. Six supermarkets can be divided into good reputation evaluation group represented by Yonghui and general reputation evaluation group represented by Ren Renle. 3. Compared with the younger generation, middle-aged and elderly Chinese consumers trust the goods recommended by the staff of the supermarket more and pursue the low price more. 4. Whether the development prospect of the supermarket enterprise is broad or not is an important consideration for customers to evaluate its reputation. 5. Consumers have a weak perception of customer orientation and social responsibility, such as whether the supermarket safeguards its rights and interests, and whether it bears social responsibility.

Based on this, the comprehensive supermarket in the Chinese market can be considered in the daily management: First, strictly control product quality, ensure product quality at the same time to benefit consumers. Second, pay more attention to employee management, motivate employees to improve their service ability and improve customers' shopping experience through skills training, service concept enhancement and performance rewards. Third, clarify market positioning, foreign-funded supermarkets such as ITO can create quality life for young urban white-collar workers and maintain a stable and loyal customer base. Fourth, strengthen public opinion monitoring, effectively crisis public relations, timely respond to negative news, and maintain corporate image. Fifth, justice takes social responsibility, actively responds to garbage environmental treatment and charity fund-raising events, and take advantage of the media to explain effective communication of reputation signals to win customers' favor.

\subsection{Limitations and further research}

This paper studied the comprehensive supermarkets with a large number of 6 stores in Chengdu region, but did not include all the comprehensive supermarkets in the region, such as RT-MART. Future research can expand the research object and research field, such as the reputation evaluation of drug supermarkets and department stores. Future research can expand the research object and research field, such as the reputation evaluation of drug supermarkets and Emporium. At the same time, the index of customer orientation in the research scale has a poor effect, which needs to be improved and improved by combining with the characteristics of enterprises. Furthermore, in order to examine the effect of reputation on supermarkets, the relationship between reputation and operation performance of supermarkets can be quantitatively analyzed in the future.

\section{References}

[1] WANG Gao;Li Fei;LU Qi-bin, A Case Study of the Degrees of Satisfaction to Customers Afforded by China's Main Chain Comprehensive Supermarkets. [J] Management World,2006(6):101-110.

[2] PU Jie, Researching the Impact of Customer-perceiving Corporate Reputation on Purchase Intention[D]. Southwest University of Finance and Economics,2009:1-2.

[3] LI Xinchen;YUAN Qinjian;SHEN Hongzhou;HOU Zhiping, Research on Reputation Measurement of E-Business Firm from the Perspective of Consumer[J]Soft Science-2016,30(11):127-130.

[4] C. J. Fombrun, Reputation : Realizing value from the corporate image, Boston : Harvard Business School Press,pp.72,1996.

[5] C. J. Fombrun and C.V. Riel, The reputational landscape, Corporate Reputation Review,vol.1,pp.5-14,1998. 
[6] ZHAO Chunyu; FENG Ying, Research on the Impact of Corporate Reputation for Innovation Performance[J]. Scientific Management Research , 2010,28(2):34-37.

[7] QU Yiying;ZHEN Jie;REN Hao ,The Impact of Corporate Reputation on Innovation Capacity and Innovation Performance in the Innovation Clusters[J]Soft Science, 2012,26(1):11-15.

[8] BAI Yongxiu; Xu Hong, On market order and corporate reputation [J]. Fujian Tribune(The Humanities \&Social Sciences Monthly),2001(6):71-74.

[9] LIU Yuyu;LOU Zhuo;LIU jun,The Influencing Factors of Corporate Reputation and its Impact on Consumers' Word-of-Mouth Behavior[J]. Chinese Journal of Management,2009,6(3):348-353.

[10]S.L. Wartick, Measuring corporate reputation:Definition and data, Business and Society,vol.41(4),pp.371-392,2002.

[11]XU Jinfa; GONG Yangda; LIU Zhigang,Study on the Mechanism of Corporate Reputation on Customer Loyalty [J] .Foreign Economies and Management.2005,27(7):44-50.

[12]LI Haiqin; ZHANG Zigang; An Empirical Study on the Effects of Corporate Social Responsibility on Corporate Reputation and Customer Loyalty[J]. Nankai Business Review,2010,13(1):90-98.

[13]HU Baoling; Yun Lexin, Empirical Study on the Influencing Factors of Online Customer Purchase Intention -- the Intermediary Role of Customer Trust.[J]Consumption Economy. 2009(4):35-39.

[14]G. Walsh, S.E. Beatty, and E. M. K. Shui, The customer-based corporate reputation scale: Replication and short form. Journal of Business Research,vol.62(10),pp.924-930,2009.

[15]MIAO Rong; MAO Ning, An Empirical Study on The Construction of Reputation Measurement Indexes of Chinese Companies [J].Nankai Business Review, 2007,10(1):91-98.

[16]C. Fornell, M. D. Johnson, E. W. Anderson, and B. E. Bryant, The American Customer Satisfaction Index: Nature, Purpose, and Findings. Journal of Marketing,vol.60(4),pp.7-18,1996.

[17]S. Aydin, and G. Özer, The analysis of antecedents of customer loyalty in the Turkish mobile telecommunication market. European Journal of marketing,vol.39(7/8),pp.910-925,2005.

[18]XIE Suhua; LIN Xiaoping; HUANG Chongwei. Dimension-reduced Processing of Western China Road and Transport Scientific and Technical Project Evaluation Index System Based on Factor Analysis[J]. Journal of Highway and Transportation Research and Development,2009,26(4):148-153. 